\title{
An Ongoing Ethnogenesis? Examining the Evolution of the Métis ${ }^{1}$
}

\author{
Christoph Laugs, University of Trier
}

George Colpitts, Pemmican Empire: Food, Trade, and the Last Bison Hunts in the North American Plains, 1780-1882 (Cambridge: Cambridge University Press, 2015). 303 pp. $\$ 90.00$ Hardcover.

Gerhard J. Ens and Joe Sawchuk, From New Peoples to New Nations: Aspects of Métis History and Identity from the Eighteenth to the Twenty-First Centuries (Toronto: University of Toronto Press, 2016). 687 pp. \$48.95 Paperback.

While the question "Who is Métis?" has been heavily debated in recent years, other topics of Métis history are similarly controversial. ${ }^{2}$ Ethnogenesis, the process during which the Métis became a distinct people, is one of them. Although Métis ethnogenesis has been studied intensively, it is still "an ill-defined process" as Nicole StOnge and Carolyn Podruchny have argued. ${ }^{3}$ While many scholars agree that such a process did occur, most of the ethnicity's traits - including the spatial and temporal dimensions as well as the people involved - are disputed. Often, the ethnogenesis is closely linked to the question of who is Métis. On the one hand, a definition of Métis might aid the analysis of an ethnogenesis. On the other hand, examining Métis ethnogenesis might lead to a definition of the term Métis. George Colpitts as well as Gerhard Ens and Joe Sawchuk offer new insights into the process of ethnogenesis with their latest books. While Ens and Sawchuk address the issue explicitly, Colpitts does so implicitly. Yet, both works advance the study of Métis ethnogenesis.

In Pemmican Empire, George Colpitts examines a specific aspect of late eighteenth- and nineteenth-century life on the Great Plains and an important economic component of the Métis ethnogenesis: the bison hunts and the production of pemmican, a food made of fat and dried meat. Colpitts' key thesis is that food in general and pemmican in particular were central to the functioning of the fur trade and a driving force of western Canadian history. ${ }^{4}$ While many scholars have pointed out that extensive hunting led to the near extinction of the bison in the late nineteenth century, Colpitts aims to analyze the "social and political dynamics" of food exchanges as well as changing environmental and economic factors on the Canadian portion of the Great Plains. ${ }^{5}$ He argues that pemmican was essential for the fur trade and that it would have been impossible for fur companies to establish their immense trading network penetrating deep into western and northern Canada without pemmican. In the context of the fur trade, Colpitts identifies two important properties: its high caloric value of up to 3,500 calories per pound - with labourers 
needing between 4000 and 7000 calories per day - and its shelf life, which could be "almost indefinite," and aided operations far away from trade posts. ${ }^{6}$ Additionally Colpitts examines how, from the 1820 s onwards, the production of pemmican became an economic niche which was occupied mostly by Métis people.

The incorporation of several methodological approaches is the great achievement of Colpitts' book. He writes that he is "integrating the fields of Native and Métis history with Northern Plains environmental history."7 However, his approach is much more comprehensive and Colpitts employs elements from the fields of environmental history, economic history, Indigenous history, as well as the emerging field of food history. As food history has broadened from culinary history, which analyzes the history of cooking and preparing food, to addressing all facets of food production and consumption, it can combine aspects from different historical disciplines: e.g. immigration history, social history, and the history of technology. ${ }^{8}$ Pemmican Empire is an outstanding example of a food history approach as Colpitts demonstrates how food - in this case pemmican - can serve as a linchpin to understand and tell history. However, he does not emphasize the innovative viewpoint of food history explicitly. Instead, he highlights the environmental aspect of his study and draws on the research of Frank Roe and Dan Flores, who have analyzed the climatic and ecological changes on the Great Plains in the nineteenth century to investigate the near-extinction of the bison. ${ }^{9}$ Colpitts extends this environmental history approach by analyzing how the northern Great Plains ecoregion was subject to a significant change caused by intensive and non-sustainable bison hunting. Additionally, he bases his research on a large corpus of literature at the intersection of Indigenous and economic history. Scholars like Arthur Ray and Frank Tough have studied the role of Indigenous people in the fur trade and the effects of the non-sustainable economic system on them. ${ }^{10}$ Whereas many studies have focused primarily on First Nations, Colpitts centres on Métis people. Regarding bison as part of the "natural resource commons" and thus open to everyone, he analyses the economic system of pemmican production and trade and examines Métis people's options and choices. ${ }^{11}$ Taking up Gerhard Ens' argument that the integration in a wider market economy determined Métis life at Red River, ${ }^{12}$ Colpitts argues that the production and trade of pemmican were central aspects of the Métis' "market orientation" and thus a key aspect of the "history of Métis ethnogenesis."13

George Colpitts investigates sources from different archives and bases his analysis on a solid and impressive array of source material. The largest group of material originates from the Hudson's Bay Company and includes post journals, letters, and account books. With them, he reconstructs where and when the company purchased pemmican and analyzes prices and quantities of sales to show how the Hudson's Bay Company used its monopoly to beat down the price of pemmican. In addition, Colpitts analyses various private, governmental, and ecclesiastical records - including for example the Selkirk Papers dealing with the establishment of the Red River settlement. The second important group of sources for Colpitts' 
analysis are published narratives - including travel narratives written by European and Euro-Canadian travellers, memoirs written by fur traders, and compendiums for prospective settlers, which include accounts of bison hunts and descriptions of the taste and texture of pemmican. Moreover, he examines, how fur traders, administrators, and settlers perceived pemmican as an essential foodstuff. Although his sources provide a comprehensive view on bison hunts and pemmican production in the late eighteenth and nineteenth century, the vast majority of them are Euro-Canadian. It is unfortunate that Indigenous sources only play a minor role in the analysis, especially since Colpitts has researched Indigenous stories about food, particularly pemmican. ${ }^{14}$ Although he includes some Indigenous written sources including the published memoirs of Peter Erasmus and Norbert Welsh or archival records such as the manuscripts of Marie Rose Smith - the book would benefit from more Indigenous sources such as, for example, interviews with Indigenous people about their family stories of bison hunting. Additionally, expounding the problems of the available source material on western Canada to readers who are unfamiliar with the subject, as Colpitts has done in other publications, would improve the book. ${ }^{15}$

George Colpitts' book is structured chronologically. However, he does not build the chapters around key moments or turning points of Western Canadian history like the Battle of Seven Oaks or the Resistances of 1869/70 and 1885. Instead, he presents a narrative of pemmican in western Canada in six parts or stages. As Colpitts covers a large geographic area, some processes occurred in different locations earlier than in others. Moreover, the advances from one stage to the next are marked by gradual change and processes rather than by concise turning points and events so that the temporal placement of the stages is relatively broad. The first covers the emerging fur trade in the second half of the eighteenth century. As the trade expanded, the food and energy needs grew steadily. Colpitts analyses why pemmican produced by Dene and other Indigenous peoples was an ideal solution for these needs. Around the turn of the nineteenth century, the second stage saw European fur traders and Indigenous people establish economic networks that originated in Indigenous sharing and exchange systems but gradually became more market-orientated. Colpitts illustrates this market orientation with the example of "trade pemmican" which was faster and cheaper to produce and which needed fewer ingredients than traditional pemmican. ${ }^{16}$ As the demand soon outgrew the supply, in a third stage, the trade and the prices were controlled by the producers. The competition between different fur trade companies and a short supply led to rising prices of pemmican resulting in three consequences: more people - particularly Métis started to make pemmican, tensions between buyers of pemmican grew, and the Hudson's Bay Company attempted to outlaw the export of pemmican from its lands. The latter two phenomena led to the "Pemmican Wars" of the 1810s and eventually to the merger of the North West Company and the Hudson's Bay Company in $1821 .{ }^{17}$ This merger is the only exact turning point Colpitts identifies be- 
tween the stages of the history of pemmican.

In the fourth stage, the Hudson's Bay Company employed bison hunters to reduce its dependency on buying pemmican. As the only remaining large fur trade company, its influence on prices was strong. Consequently, the prices for pemmican fell drastically and it became harder for Indigenous people to profitably make pemmican. The falling prices lead to a fifth stage, which Colpitts dates roughly between 1835 and 1850 and in which Indigenous people had to face economic challenges. In order for bison hunts to be economically sensible, they had to produce large quantities of pemmican. Thus, the nature of the hunts changed and they rapidly grew in size and output. At the same time, the main hunting season shifted from the winter to the summer, increasing the amount of pemmican produced. Yet, this shift also led to a hunting and pemmican production style which Colpitts characterises as "wasteful" since many parts of the animals remained unused and it contributed to the decimation of bison on the Great Plains. ${ }^{18}$ Colpitts identifies the declining bison population and the possibility of trading in the United States as the main characteristics of his sixth and last stage. The possibility to trade internationally presented "new, but narrower options" to Indigenous peoples who produced pemmican. ${ }^{19}$ From the 1850 s on, a transportation revolution with railroads and steamboats, however, meant that the Hudson's Bay Company needed fewer labourers and consequently bought less pemmican. Additionally, the new means of transport allowed the company to import food from eastern Canada. Thus, Colpitts argues that the near-extinction of the bison is both: the result of and the end for the Pemmican Empire.

Pemmican Empire offers an impressive new angle on Western Canadian and Métis history. While the subject itself has been addressed partially in many studies and books on Métis and Western Canadian history do without a view on bison hunts, Colpitts' pemmican-centred approach provides new insights and highlights the role of pemmican as the "driving energy source" in western Canada. ${ }^{20} \mathrm{His}$ argument is well plotted and rigorous. Moreover, it is easy for readers to follow the six stages of pemmican history as Colpitts guides them and highlights the link between the individual chapters. Therefore, readers get the impression that every stage is not only a result of the processes in the previous one but almost the logical consequence. Although Colpitts uses Indigenous archival material wherever possible, the book reflects a rather Euro-Canadian view and a predominantly male perspective. It is comprehensible that Colpitts focused on archival sources, but Colpitts should explain his choices in the book. The same applies to the naming of events and places. For example, Colpitts uses the term Métis with acute accent. Since the spelling is debated among scholars, a short note would be helpful to readers. ${ }^{21}$ The glossary on food-related terminology provided in the appendix is very useful. Colpitts' culinary knowledge aids his analysis of the different types of pemmican and the distinctions in production, shelf life, and taste. Overall, George Colpitts provides a new approach to one of the central aspects of Métis history. His book is not an 
introduction to the history of food in western Canada, but it is accessible for a broad readership unfamiliar with western Canadian history, and it provides new information to readers who are acquainted with western Canadian and Métis history. Through the history of pemmican as a foodstuff, Colpitts joins together different approaches to Western Canadian history and shows that pemmican did not only feed people but also fed the development of the Canadian West and the evolution of the Métis.

In contrast to the specific focus of Pemmican Empire, Gerhard Ens and Joe Sawchuk address the broader question of when and how the Métis ethnogenesis occurred in their book From New Peoples to New Nations. Ens and Sawchuk examine aspects of Métis history from the late eighteenth century until the early 2010s and see the main objective of their book as placing the current struggles of the Métis in a historical and political context. ${ }^{22}$ This aim might sound as if they compiled a comprehensive Métis history handbook, a task not undertaken since the 1950s. Yet, they state that they "abandoned the idea of providing a comprehensive and complete history" after the death of John Foster who was part of the project when it evolved over a decade ago. ${ }^{23}$ Nevertheless, Ens and Sawchuk analyze aspects of Métis history in a wide temporal and geographic range. Their main finding and principal argument is that Métis ethnicity and identity evolved as "the product of a dialogical process between how the Métis viewed themselves and how others... perceived" them. ${ }^{24}$ While they acknowledge the role of ancestry, kinship networks, and culture, they argue convincingly that Métis identity was shaped mainly by a legal and governmental framework. The book reveals that the development of Métis ethnicity and identity was not just Métis people's reaction to external factors but rather a process of constant (re-)negotiation between Métis and Euro-Canadians. Ens and Sawchuk demonstrate that the processes of negotiation have shifted significantly over time and that the ongoing court cases on Métis status and Métis rights are a continuation of historic processes and discussions. Thus, they argue that there is an "ongoing Métis ethnogenesis." 5

One of the excellent features of From New Peoples to New Nations is its interdisciplinary approach to Métis history, due mainly to the diverse backgrounds of the authors. Gerhard Ens is a historian who has previously worked on the Métis in the nineteenth century and has also focused on Métis collective memory and memory culture. ${ }^{26}$ Joe Sawchuk is an anthropologist who has engaged with Métis identity and ethnicity and worked with Métis communities since the early 1970 s. $^{27}$ In their book, they succeed in combining their expertise and link a historic hermeneutic approach with an anthropological approach centred on Métis communities. They distance themselves from the view that the Métis were and are "primordialist," i.e. the view that the evolution of the Métis Nation is the result of fixed preconditions such as kinship, language, or religion. ${ }^{28}$ Instead the authors take a social constructivist and instrumentalist perspective and link it with considerations of imagined communities and invented traditions. ${ }^{29}$ Thus, they see Métis ethnicity as situational 
and strategic as well as a social construct, resulting from dialogues between insider and outsider views. Yet, when defining the term Métis, Ens and Sawchuk "put the focus on the ethnic group rather than on a way of life." 30 They join the growing group of scholars who reject the notion of mixedness and hybridity as defining characteristics. Thus, they focus on Métis people in western Canada rather than on all groups with a mixed Indigenous and Euro-Canadian ancestry. ${ }^{31}$ Based on this ethnic focus, they analyze culture, economy, and politics as strategies of distinction and, hence, define the Métis in the context of the Euro-Canadian settler imperialism.

Gerhard Ens and Joe Sawchuk took up the gargantuan task of integrating more than five decades of academic and community research into their study. Since the late 1940s, scholars have mostly referred to three comprehensive and complete Métis history books: George Stanley's The Birth of Western Canada, Marcel Giraud's le Métis canadien, and Auguste Henri de Trémaudan's Histoire de la Nation Métisse dans l'Ouest Canadien. ${ }^{32}$ While Giraud was read primarily by Francophone academics, Stanley was received in English-speaking academia and Trémaudan was adopted to a much lesser extent by both. The continuing reference to these books as a major source for Métis history is problematic for three reasons. First, much has happened for the Métis since the 1930s and 1940s. Second, the history books have been criticized heavily. Stanley and Giraud wrote from a Euro-Canadian perspective using almost exclusively Euro-Canadian archival material. And third, the last decades have seen a lot of academic and community engagement with Métis history, identity, and culture which have revealed many new insights and conclusions. Ens and Sawchuk heavily criticize the early social science research among Métis communities in the 1950s and 1960s, which provided "limited insights" and ignored Métis views and perspectives. ${ }^{33}$ While many scholars of Métis history have ignored Trémaudan's book, Ens and Sawchuk examine not only the book itself but also the process of its completion. They analyze the writing and publishing of the Histoire de la Nation Métisse dans l'Ouest Canadien in the context of Métis self-organization in the 1930s. ${ }^{34}$ Thus, they argue that it was a primarily political work heavily influenced by the Union Nationale Métisse Saint-Joseph du Manitoba and that it was an "important step" towards the Métis' political self-organization. ${ }^{35}$ Moreover, they implicitly suggest that scholars should read Trémaudan's book rather than Giraud's.

A look at the source material Ens and Sawchuk used for their project reveals that their book does not simply summarize existing scholarship on Métis history, but also includes extensive new research undertaken for the book. They draw on and incorporate many recent studies and publications from different fields of Métis history, but the basis for their analysis comprises primary source material, including Euro-Canadian archival material that has been used by many, if not most, historians writing about the Métis. They also use many sources that offer a Métis point of view which help to analyze the dialogue of insider and outsider views that shaped Métis ethnicity and identity. The first group of sources comprise govern- 
mental and church papers as well as the records of the Hudson's Bay Company, all three of which have formed the basis for many studies on western Canadian history. Ens and Sawchuk do an excellent job at incorporating material from archives in both Canada and the USA. Additionally, they have put a special focus on private fonds. While many have been compiled by Euro-Canadians, such as for Archbishop Alexandre-Antonin Taché, the authors have also analyzed several archival estates left by Métis, such as the papers of Louis Riel and the fonds of Albertan Métis leaders James Brady and Joseph Dion. These sources help Ens and Sawchuk to examine the insider view on Métis identity. In addition to archival sources, they also use interviews with Métis people conducted as part of oral history or anthropological research. They include both archived interviews and interviews conducted by the authors themselves. An example for the former are interviews conducted among the Teton and Dupuyer Metis Communities in Montana and the latter encompass several dozens of interviews conducted primarily in the late 1980s and the 1990s. The mixture of archival, published, and oral source material on the one hand, as well as both Métis and Euro-Canadian perspectives on the other hand, makes From New Peoples to New Nations impressive and allows the authors to identify and examine the dialogic processes between insider and outsider views on Métis ethnicity and identity.

Gerhard Ens and Joe Sawchuk have structured their book into eighteen chapters that they have sorted thematically into five parts. Within those, they have arranged the chapters chronologically. Although the five parts have temporal foci which follow a chronological order, the time periods examined overlap. The first part of the book addresses the terminology of hybridity and ethnogenesis. Ens and Sawchuk discuss different views of these terms and processes, arguing that the meanings and implications of analytical terms widely used today changed significantly over the last centuries. The term nation for example does not mean the same to today's historians as it did to Louis Riel or to Métis organizations in the early twentieth century. ${ }^{36}$ Moreover, Ens and Sawchuk address the role of the fur trade for the Métis and argue that it served as a "catalyst" for their evolution. ${ }^{37}$ In the second part of their book, Ens and Sawchuk address the history of the concept of the Métis Nation and examine how it became "the dominant narrative of Métis history." 38 They argue that Métis people had developed a sense of belonging by the 1850 s, but rarely - if ever - used the term nation. ${ }^{39}$ The term came into wider use between the two resistances and was shaped significantly by Trémaudan's Histoire de la Nation Métisse dans l'Ouest canadien. Ens and Sawchuk interpret the book as "a highly effective story" which manifested the self-perception of Métis elites in Manitoba of the $1930 \mathrm{s.}^{40}$

In part three, Ens and Sawchuk focus on government policies towards the Métis and their responses. They argue that the Canadian government relatively quickly ignored the promises made to Métis people in the Manitoba Act of 1870, which left most Métis with the choice of "entering treaty or taking scrip," examining 
the implications of each. ${ }^{41} \mathrm{~A}$ further focus is the role of the Canada-US border both as a refuge for Métis people and as a divide of government policies towards them. In this context, Ens and Sawchuk contend that, as a result of US policy, many Métis communities in the US sought recognition as First Nations so that few of them referred to themselves as Métis between the 1880s and 1930s. ${ }^{42}$ In the fourth part, Ens and Sawchuk focus on the economic marginalization of Métis people and their political responses during the time between the resistances and the 1960s, which some scholars call the "Forgotten Years." ${ }^{33}$ They explain that the primary aim of the scrip programs - to provide land bases for Métis people - failed for several reasons and resulted in economic marginalization of many Métis people. In this context, they analyse three counter strategies: one organized by the church, one by a provincial government, and one by Métis themselves. Along with the St-Pauldes-Métis colony around 1900 and the formation of the Métis Association of Alberta in the 1930, which Ens and Sawchuk see as a continuation of existing leadership structures, they examine the politics of Liberal and CCF governments in Saskatchewan. ${ }^{44}$ Especially for the CCF, they argue that the government was interested in improving conditions for Métis people without promoting the formation of a Métis identity. ${ }^{45}$ In the fifth part, they focus on Métis identities since the 1960s particularly in Manitoba, Ontario, and the North-West Territories. Besides political and legal debates, they also address the role of Métis symbols and their role in collective memory, focusing on the sash and the Red River cart.

Gerhard Ens and Joe Sawchuk achieve two thing with From New Peoples to New Nations. On the one hand, they draw together decades of research on Métis history and identity and provide a comprehensive overview on the history of the concepts of Métis Nation and Métis identity. On the other hand, they further our knowledge of Métis with new research. In addition, they provide useful insights into Métis historiography, explaining how the writing of Métis history had significant impacts on Métis lives. Above all, Ens and Sawchuk integrate existing research into their argument and make a strong case for an ongoing Métis ethnogenesis, which is far from complete and probably never will be. This argument comprises the two main strengths of the book. The first is the link of historical development with current political debates and the second is the acknowledgement that the book cannot cover each and every aspect of Métis history and identity. While the book is easy to read, it is aimed at those with a basic knowledge of Métis history and culture, which becomes apparent especially in the last chapter in which Ens and Sawchuk analyse Métis symbols. For example, the Red River cart, which they see as the most important symbol of Métis people, is analyzed without a detailed description. This omission of lengthy descriptive passages helps to keep the book as succinct as possible, though. Moreover, the authors provide an eminently useful introduction that outlines their use of terminology as well as a brief definition of whom they see as Métis which can serve as an example for future studies. All in all, Gerhard Ens and Joe Sawchuk wrote an excellent book on Métis history and identity. Al- 
though From New Peoples to New Nations is not a complete and comprehensive Métis history book, it contains chapters on many aspects and extends into new areas, which reflects the advancements and turns of academic and community research on Métis history and identity of the last decades.

Although George Colpitts' Pemmican Empire and Gerhard Ens and Joe Sawchuk's From New Peoples to New Nations address the issue of Métis ethnogenesis in two seemingly completely different ways, it is possible to see Colpitts' study as an aspect of Ens and Sawchuk's argument. When comparing Pemmican Empire to Chapter Two of From New Peoples to New Nations, two things become visible. First, both argue that the role of the Métis in the fur trade was an integral part of their ethnogenesis. And second, Ens and Sawchuk have to leave out individual aspects of Métis history to fit their argument into one book, aspects which are fully elaborated by Colpitts. Thus, From New Peoples to New Nations and Pemmican Empire complement one another. While Ens and Sawchuk provide the wider context for Colpitts' study, Pemmican Empire elaborates on details that go far beyond the scope of From New Peoples to New Nations. The same applies, of course, to other books and articles on Métis history and identity and their relation to Ens and Sawchuk's book. For example, Michel Hogue's Metis and the Medicine Line, which discusses the role of the Canadian-US border, relates to Chapter Nine, and Chris Andersen's "Métis," which criticizes legal definitions of the term Métis, connects to Chapter Fifteen. ${ }^{46}$

Ens and Sawchuk's book reveals two further points. First, writing a complete and concise Métis history book, which also aims at a readership unfamiliar with the discipline, is a gargantuan but necessary task. While such a history book would have to skip over many details and simplify many aspects of Métis history, the history of the Métis as well as its historiography has progressed so significantly since the 1940s that it is time for such a book to be written. Second, and most important, following Ens and Sawchuk's argument that the Métis ethnogenesis is ongoing and that it is a dialogic process between insider and outsider views, it becomes clear that we all are part of it. Like governmental actors and courts of law, the academic community is an essential element of this process. From undergraduate students to full professors, we should be conscious of our role in the ongoing Métis ethnogenesis. 


\section{NOTES}

${ }^{1}$ As Métis is written with a capital 'M' and an acute accent in both of books, I am reviewing in this essay, the spelling is adopted for this review article.

${ }^{2}$ On the debate about this question, see for example: Hayter, Jennifer: "Métis Identity: Problems and Possibilities," Left History 18.2 (2015): 53-66.

${ }^{3}$ Nicole St-Onge and Carolyn Podruchny, "Scuttling along a Spider's Web: Mobility and Kinship in Metis Ethnogenesis," in Contours of a People: Metis Family, Mobility, and History, ed. Nicole St-Onge, Carolyn Podruchny, and Brenda Macdougall (Norman, OK: University of Oklahoma Press, 2012), 59.

${ }^{4}$ Colpitts argues for two differences between the history of bison hunting in Canada and in the United States. First, pemmican was a peculiarity of the northern Great Plains, as the climatic conditions further south did not favour the production and storage of it so that jerky was more common there. Second, food production was the driving force for increased bison hunting in Canada, whereas In the United States it was the trade in skins and robes.

${ }^{5}$ George Colpitts, Pemmican Empire: Food, Trade, and the Last Bison Hunts in the North American Plains, 1780-1882 (Cambridge: Cambridge University Press, 2015), 2.

${ }^{6}$ Colpitts, Pemmican Empire, 31-33, 99.

${ }^{7}$ Colpitts, Pemmican Empire, 7.

${ }^{8}$ Barbara Haber, "Culinary History Vs. Food History," in: The Oxford Companion to American Food and Drink, ed. Andrew F. Smith (Oxford: Oxford University Press, 2007), 179-180.

${ }^{9}$ Dan L. Flores, The Natural West: Environmental History in the Great Plains and Rocky Mountains (Norman, OK: University of Oklahoma Press, 2001); Frank G. Roe, The North American Buffalo: A Critical Study of the Species in Its Wild State (Toronto: University of Toronto Press, 1951).

${ }^{10}$ Arthur J. Ray, Indians in the Fur Trade: Their Role as Trappers, Hunters, and Middlemen in the Lands Southwest of Hudson Bay, 1660-1870 (Toronto: University of Toronto Press, 1974); Frank Tough, "As their Natural Resources Fail”: Native Peoples and the Economic History of Northern Manitoba, 1870-1930 (Vancouver: University of British Columbia Press, 1996).

${ }^{11}$ Colpitts, Pemmican Empire, 4.

${ }^{12}$ Gerhard J. Ens, Homeland to Hinterland: The Changing Worlds of the Red River Metis in the Nineteenth Century (Toronto: University of Toronto Press, 1996).

${ }^{13}$ Colpitts, Pemmican Empire, 7.

${ }^{14}$ Ibid., 11-13. 
${ }^{15}$ George Colpitts, North America's Indian Trade in European Commerce and Imagination, 1580-1850 (Leiden: Brill, 2013), 16-17.

${ }^{16}$ Colpitts, Pemmican Empire, 96.

${ }^{17}$ Ibid., 99.

${ }^{18}$ Ibid., 261.

${ }^{19}$ Ibid., 218.

${ }^{20}$ Ibid., 3.

${ }^{21}$ Such notes on terminology can be found for example in: Contours of a People:

Metis Family, Mobility, and History. ed. Nicole St-Onge, Carolyn Podruchny, and

Brenda Macdougall (Norman, OK: University of Oklahoma Press, 2012), xxix.

${ }^{22}$ Gerhard J. Ens and Joe Sawchuk, From New Peoples to New Nations: Aspects of

Metis History and Identity from the Eighteenth to the Twenty-First Centuries (Toronto:

University of Toronto Press, 2016), 4.

${ }^{23}$ Ens and Sawchuk, New Peoples to New Nations, 8.

${ }^{24}$ Ibid., 509.

25 Ibid., 514.

${ }^{26}$ Including: Ens, Homeland to Hinterland.

${ }^{27}$ Including: Joe Sawchuk, The Metis of Manitoba: Reformulation of an Ethnic Identity (Toronto: P. Martin Associates, 1978).

${ }^{28}$ Ens and Sawchuk, New Peoples to New Nations, 6.

${ }^{29}$ Benedict R. Anderson, Imagined Communities: Reflections on the Origin and Spread of Nationalism (London: Verso, 1991), 6; Eric Hobsbawn, "Introduction: Inventing Traditions," in The Invention of Tradition. ed. Eric Hobsbawn and Terence Ranger (Cambridge: Cambridge University Press, 1983), 1.

${ }^{30}$ Ens and Sawchuk, New Peoples to New Nations, 4.

${ }^{31}$ Chris Andersen, "Métis": Race, Recognition, and the Struggle for Indigenous Peoplehood (Vancouver: UBC Press, 2014).

${ }^{32}$ Auguste-Henri de Trémaudan, Histoire de la Nation Métisse dans l'Ouest Canadien. (Montreal: Éditions Albert Lévesque, 1935); George F. G. Stanley, The Birth of Western Canada: A History of the Riel Rebellion (Toronto: University of Toronto Press, 1936); Marcel Giraud, Le Métis Canadien: Son Rôle Dans L’histoire Des Provinces de l'Ouest (Paris: Institut d'ethnologie, 1945).

${ }^{33}$ Ens and Sawchuk, New Peoples to New Nations, 358.

${ }^{34}$ Ibid., 113-129.

35 Ibid., 129.

36 Ibid., 40. 
${ }^{37}$ Ibid., 66.

38 Ibid., 68.

${ }^{39}$ Ibid., 91.

${ }^{40}$ Ibid., 123.

Ibid., 155.

Ibid., 238.

Fred J. Shore, "The Emergence of the Métis Nation in Manitoba," in Metis

Legacy: A Metis Historiography and Annotated Bibliography, ed. Lawrence J. Barkwell, Leah Dorion, and Darren R. Préfontaine (Winnipeg: Pemmican Publications, 2001), 72-78.

Ens and Sawchuk, New Peoples to New Nations, 257.

Ens and Sawchuk, New Peoples to New Nations, 306.

${ }^{46}$ Michel Hogue, Metis and the Medicine Line: Creating a Border and Dividing a People (Regina: University of Regina Press, 2015); Andersen, "Métis". 